\title{
HEALTHCARE SERVICES USE AMONG DENTAL PATIENTS
}

\section{Oancea Roxana1, Sfeatcu Ruxandra², Gheorghiu Irina Maria33, Mihai Mitran4, Loredana Mitran5, Iliescu Alexandru-Andrei ${ }^{6}$, Paula Perlea ${ }^{7}$}

${ }^{1}$ Department of Preventive Dentistry, Community and Oral Health, Faculty of Dental Medicine, UMF "Victor Babes" Timisoara

${ }^{2}$ Department of Oral Health and Community Dentistry Faculty of Dental Medicine, UMF "Carol Davila" Bucharest

${ }^{3}$ Department of Restorative Odontotherapy, Faculty of Dental Medicine, UMF "Carol Davila" Bucharest

${ }^{4}$ Department of Obstetrics and Gynecology, Faculty of Medicine, UMF "Carol Davila" Bucharest

${ }^{5}$ Department of Otorhinolaryngology, Elias Hospital

${ }^{6}$ Department of Oral Rehabilitation, Faculty of Dental Medicine, UMF Craiova

${ }^{7}$ Department of Endodontics, Faculty of Dental Medicine, UMF “Carol Davila” Bucharest

Gheorghiu Irina-Maria

Faculty of Dental Medicine, UMF “Carol Davila” Bucharest Calea Plevnei 17-23, Bucharest email:igheorghiu@hotmail.com

\begin{abstract}
Regular medical attendance proved to have a positive impact on health, therefore the aim of the study is to detect the reasons and frequency for health care use among a group of 110 urban dental patients aged between 33 and 75 years, $50 \%$ males. The subjects completed an anonymous questionnaire with items related to their medical visits patterns: reason (treatment/control and emergency) and frequency of healthcare services use; self-assessed oral and general health and socio-demographic data. Most of the patients were adults (81.8\%) and with more than 12 years of study (50\%). In terms of reason for attending the dental office, $72 \%$ visited the dentist for emergency reasons, mainly men, elderly, patients with low level of education, and those who self-rated their oral health as satisfying or poor. Regarding medical visits, 54\% from all patients attended healthcare for emergency reasons, regardless age, gender, education level and self-perceived general health. The results showed that worse healthcare services use is associated with low education level and gender, especially men visited the dentist when there is pain only. There is need to increase the number of individuals who use regular health care, for prevention and early detection of diseases.
\end{abstract}

Keywords: medical attendance, dental visits, unhealthy behaviours

\section{Introduction}

Healthcare services are accessed for the main two motives: prevention and curative treatment of medical problems. Regular dental and general attendance proved to have a positive impact on health status, therefore it is important to find and understand the reasons for incorrect medical care of individuals (1). This information is important especially for health care decision makers involved in shaping and developing the health policy interventions for improving population health $(1,2)$. For clinicians, there is a need to deliver comprehensive medical care in a patient-centered approach health, prioritizing the interventions towards increasing regular dental and general services use, considering the impact of health on individuals' lives $(2,3)$. Regular medical care provides the opportunity for improved health outcomes, preventive treatments and early detection of dental and general diseases $(4,5)$.

The objectives of Healthy People 2020 are to integrate dental and primary health care and to increase the proportion of individuals who use medical care in the past year, both as opportunities for primary and secondary prevention $(4,6)$.

The aim of this study is to assess the main reasons and frequency of health care use among a group of urban dental patients. 


\section{Materials and methods}

In this study were included 110 patients (50\% females), aged between 33 and 75 years old. They received and agreed to complete an anonymous questionnaire with items related to their medical visits habits (reason and frequency of healthcare services use), self-assessed oral and general health and socio-demographic data (age, gender and education level).

In terms of self-perceived health status was used a 5 points Likert scale (excellent, very good, good, satisfying and poor). About the main reason for medical attendance the participants had to choose between treatment/control and emergency. For frequency of visiting the dental and medical offices were there answers: every 6-12 months, in case of pain or problems, and even never.

For presenting the results related to selfrated health the response categories were recoded in two categories: on one hand were recorded three answers (excellent, very good, good), but then the last two responses (satisfying and poor).

The subjects were informed about the aim of the study and confidentiality.

\section{Results}

The mean age of respondents was 51.25 years $(\mathrm{SD}=12.26)$ and half of them were males. The subjects were dived in two age groups: adults until 64 years old and elderly above 65 years.

The background characteristics of participants were presented in Table I. Most of the patients were adults $(81.8 \%)$ and with more than 12 years of study (50\%). Almost half (42.7\%) of subjects had high school level and only $7.3 \%$ had 8 years of study or less.

Participants self-assessed their oral and general health mainly as good and satisfying, a few rated as very good or poor and only very few as excellent. More subjects self-perceived their oral health and being excellent, good or very good $(\mathrm{N}=62)$ versus $48(\mathrm{~N})$ who self-rated as satisfying or poor. Regarding general health, more patients rated it as being satisfying or poor $(\mathrm{N}=61)$ compared to 49 who assessed it as excellent, good or very good (see Table I).

Table I. Characteristics of participants

\begin{tabular}{|l|r|}
\hline Variables & $\mathrm{N}(\%)$ \\
\hline Gender & \\
Male & $55(50)$ \\
Female & $55(50)$ \\
\hline Age & \\
Adults (18-64 years) & $90(81.8)$ \\
Elderly ( $\geq 65$ years) & $20(18.2)$ \\
\hline Education & \\
<8 years & $8(7.3)$ \\
years & $47(42.7)$ \\
12 years & $55(50)$ \\
\hline Self-rated oral health & $3(2.7)$ \\
Excellent & $14(12.7)$ \\
Very good & $45(40.9)$ \\
Good & $38(34.5)$ \\
Satisfying & $10(9.1)$ \\
Poor & $2(1.8)$ \\
\hline Self-rated general health & $9(8.2)$ \\
Excellent & $38(34.5)$ \\
Very good & $46(41.8)$ \\
Good & $15(13.6)$ \\
Satisfying & \\
Poor &
\end{tabular}

In terms of reason for attending the dental office, most of the subjects $(72 \%)$ visited the dentist for emergency reasons (pain or oral problems), mainly men and elderly (see Table II a), patients with low level of education (less years of study) and those who self-rated their oral health as satisfying or poor (see Table II b).

Although few, 4 patients never been to dentist, all adult females, with low level of education (less than 12 years of study) and who self-assessed their oral health status as being satisfying or poor (Table III $a, b$ ).

Regarding medical visits, all patients

Table IIa. Reason for visiting dentist by age and gender

\begin{tabular}{|l|c|c|c|c|c|}
\hline \multirow{2}{*}{} & All & \multicolumn{2}{|c|}{ Gender } & \multicolumn{2}{c|}{ Interval age } \\
\cline { 2 - 6 } & $\mathrm{N}(\%)$ & Males $(\mathrm{N})$ & $\begin{array}{c}\text { Females } \\
(\mathrm{N})\end{array}$ & $\begin{array}{c}\text { Adults (N) } \\
(18-64 \text { years })\end{array}$ & $\begin{array}{c}\text { Elderly (N) } \\
(\geq 65 \text { years) }\end{array}$ \\
\hline Emergency & $79(72)$ & 43 & 36 & 62 & 17 \\
\hline Control/treatment & $27(24.5)$ & 12 & 15 & 24 & 3 \\
\hline
\end{tabular}


Table IIb. Reason for visiting dentist depending on education level and self-assessment of oral health status

\begin{tabular}{|l|c|c|c|c|c|}
\hline \multirow{2}{*}{} & \multicolumn{2}{|c|}{ Education (years of study) $(\mathrm{N})$} & \multicolumn{2}{c|}{ Self-rated oral health (N) } \\
\cline { 2 - 6 } & $\begin{array}{c}\leq 8 \\
\text { years }\end{array}$ & $\begin{array}{c}9-12 \\
\text { years }\end{array}$ & $\begin{array}{c}>12 \\
\text { years }\end{array}$ & $\begin{array}{c}\text { Excellent/ } \\
\text { (very) good }\end{array}$ & $\begin{array}{c}\text { Satisfying/ } \\
\text { poor }\end{array}$ \\
\hline Emergency & 6 & 33 & 40 & 42 & 37 \\
\hline Control/treatment & 2 & 11 & 14 & 20 & 11 \\
\hline
\end{tabular}

Table IIIa. Frequency of visiting dental office by gender and age

\begin{tabular}{|l|c|c|c|c|c|}
\hline & All & \multicolumn{2}{|c|}{ Gender } & \multicolumn{2}{c|}{ Interval age } \\
\hline & $\mathrm{N}(\%)$ & Males $(\mathrm{N})$ & Females $(\mathrm{N})$ & $\begin{array}{c}\text { Adults (N) } \\
(18-64 \text { years) }\end{array}$ & $\begin{array}{c}\text { Elderly (N) } \\
(\geq 65 \text { years) }\end{array}$ \\
\hline 6-12 months & $27(72)$ & 8 & 19 & 21 & 6 \\
\hline Pain/problems & $79(24.5)$ & 47 & 32 & 65 & 14 \\
\hline Never & $4(3.5)$ & 0 & 4 & 4 & 0 \\
\hline
\end{tabular}

Table IIIb. Frequency of visiting dental office by education level and self-assessment of oral health status

\begin{tabular}{|l|c|c|c|c|c|}
\hline \multirow{2}{*}{} & \multicolumn{2}{|c|}{ Education (years of study) $(\mathrm{N})$} & \multicolumn{2}{c|}{ Self-rated oral health (N) } \\
\cline { 2 - 6 } & $\begin{array}{c}\leq 8 \\
\text { years }\end{array}$ & $\begin{array}{c}9-12 \\
\text { years }\end{array}$ & $\begin{array}{c}>12 \\
\text { years }\end{array}$ & $\begin{array}{c}\text { Excellent/ } \\
\text { (very) good }\end{array}$ & $\begin{array}{c}\text { Satisfying/ } \\
\text { poor }\end{array}$ \\
\hline 6-12 months & 0 & 12 & 15 & 16 & 11 \\
\hline Pain/problems & 8 & 32 & 39 & 37 & 42 \\
\hline Never & 2 & 2 & 0 & 0 & 4 \\
\hline
\end{tabular}

attended healthcare, $54 \%$ for emergency reasons, especially adults and regardless age, gender, education level and self-perceived general health (Table IV a, b).

\section{Discussion}

In order to develop adequate health care policies, it is important to understand why many individuals don't seek regular medical and dental attendance throughout lifetimes. The results showed that worse healthcare services use (due to urgent problems/pain) is associated with low education level and decreased self-perception of dental health status which is confirmed by other studies $(7,8,9)$.

Also, our study revealed that participants with higher level of education tend to use regular medical care, similar with several researchers (1, $2,4,10 ; 11)$.

Especially females behave properly, visiting the dentist annually or at every six months (routine care), as in other studies $(1,7$, $10,11)$.

One limitation of the present study is that it does not assess the oral and general health of the subjects (dental caries indices, complete or partial edentulism, periodontal status, presence of general diseases, and so on). Another limit is the social desirability bias meaning that a patient

Table IVa. Reason for visiting the medical office among dental patients by age and gender

\begin{tabular}{|l|c|c|c|c|c|}
\hline \multirow{2}{*}{} & All & \multicolumn{2}{|c|}{ Gender } & \multicolumn{2}{c|}{ Interval age } \\
\cline { 2 - 6 } & $\mathrm{N}(\%)$ & $\begin{array}{c}\text { Males } \\
(\mathrm{N})\end{array}$ & $\begin{array}{c}\text { Females } \\
(\mathrm{N})\end{array}$ & $\begin{array}{c}\text { Adults (N) } \\
(18-64 \text { years })\end{array}$ & $\begin{array}{c}\text { Elderly (N) } \\
(\geq 65 \text { years })\end{array}$ \\
\hline Emergency & $59(54)$ & 30 & 29 & 53 & 6 \\
\hline Control/treatment & $51(46)$ & 25 & 26 & 37 & 14 \\
\hline
\end{tabular}

Table IVb. Reason for medical office visits by education and self-assessed health

\begin{tabular}{|l|c|c|c|c|c|}
\hline \multirow{2}{*}{} & \multicolumn{3}{|c|}{ Education level (N) } & \multicolumn{2}{c|}{ Self-assesed health status (N) } \\
\cline { 2 - 6 } & $\begin{array}{c}\leq 8 \\
\text { years }\end{array}$ & $9-12$ years & $\begin{array}{c}>12 \\
\text { years }\end{array}$ & $\begin{array}{c}\text { Excellent/ } \\
\text { (very) good }\end{array}$ & $\begin{array}{c}\text { Satisfying/ } \\
\text { poor }\end{array}$ \\
\hline Emergency & 4 & 27 & 28 & 31 & 28 \\
\hline Control/treatment & 4 & 20 & 27 & 18 & 33 \\
\hline
\end{tabular}


think it is a must to visit a medical or dental office at every six month or one a year, they can choose to answer desirably (to report a regular healthcare visit) even if this is not true (4).

\section{Conclusions}

Most of dental patients included in this study addressed to the healthcare in case of emergency, pain or dental problems. For dental visit there are subjects who never visit the dentist before, even if in a small percentage. Patients with lower level of education and who self-perceived their oral heath as being satisfying or poor are those with an inappropriate healthcare behaviour. That is why is important to implement strategy to improve medical and dental care attendance among population to optimise thier health status.

\section{Acknowledgments:}

For this article all the authors have equal contributions as the first author.

The authors thank Procter \& Gamble Mkt Romania for their support of the present study.

\section{References}

1. Listl S, Moeller J, Manski R. A multi-country comparison of reasons for dental nonattendance. Eur J Oral Sci. 2014;122(1):629.

2. Theile CW, Strauss SM, Northridge ME, Birenz S. The Oral Health Care Manager in a Patient-Centered HealthFacility. JEvid Based Dent Pract. 2016;16 Suppl(Suppl):34-42.

3. A. Murariu, C. Hanganu. Oral Health and Quality of Life Among 45- to 64-year-old Patients Attending a Clinic in Iasi, Romania. OHDMBSC. 2009;7(2):7-11.

4. Lutfiyya MN, Gross AJ, Soffe B, Lipsky MS. Dental care utilization: examining the associations between health services deficits and not having a dental visit in past 12 months. BMC Public Health. 2019:19(1):265.

5. Dumitrache AM, Sfeatcu IR, Buzea CM \& al. . Concepte si tendinte in sanatatea orala. Bucharest: Carol Davila Publishing House; 2009.
6. Healthy People 2020. Washington, DC: U.S. Department of Health and Human Services, Office of Disease Prevention and Health Promotion https://www.healthypeople. gov/2020/about-healthy-people/how-tousehealthypeople.

7. Batista MJ, Lawrence HP, Sousa M. Correction to: Oral health literacy and oral health outcomes in an adult population in Brazil. Bmc Public Health. 2017;17(1):821.

8. Berkman ND, Sheridan SL, Donahue KE, Halpern DJ, Crotty K. Low health literacy and health outcomes: an updated systematic review. Ann Intern Med. 2011;155(2):97107.

9. Holtzman JS, Atchison KA, Gironda MW, Radbod R, Gornbein J. The association between oral health literacy and failed appointments in adults attending a universitybased general dental clinic. Community Dent Oral. 2014;42(3):263-70..

10. Burgette JM, Lee, J.Y., Baker, A.D. \& al. Is dental utilization associated with oral health literacy? J Dent Res 2016:95, 160-6.

11. Manski RJ, Meyerhoefer CD. Projecting the Demand for Dental Care in 2040. J Dent Educ. 2017;81(8):eS133-eS45. 